1968 o ano que não acabou: da imaginação no poder na Europa ao estado de exceção no Brasil Ivo dos Santos Canabarro; Luane Flores Chuquel; Alef Felipe Meier

\title{
1968 O ANO QUE NÃO ACABOU: DA IMAGINAÇÃO NO PODER NA EUROPA AO ESTADO DE EXCEÇÃO NO BRASIL
}

\author{
Ivo dos Santos Canabarro ${ }^{1}$ \\ Luane Flores Chuquel ${ }^{2}$ \\ Alef Felipe Meier ${ }^{3}$
}

\begin{abstract}
RESUMO: O artigo aborda o emblemático ano de 1968 como um ano de movimentos e contestações que marcaram toda uma geração de jovens. As manifestações de 1968 agitaram a Europa, repercutiram em várias partes do mundo, inclusive no Brasil. A primeira parte da abordagem retrata o movimento em Paris como um palco das grandes manifestações de uma verdadeira revolução cultural. A segunda parte aborda as manifestações no Brasil, no ano em que vivíamos um verdadeiro Estado de exceção. Mesmo com essa condição política, os jovens foram às ruas e mostraram a sua indignação. Foi um ano de pedir imaginação no poder na Europa e no Brasil o auge de uma ditadura civil militar. Foi um período de contrastes, por isso emblemático. $\mathrm{O}$ grande legado de 1968 cinquenta anos depois é o de reviver uma memória que ainda permanece viva, que marcou gerações e que vale lembrá-lo pela coragem e ousadia dos estudantes na luta constante pelos direitos humanos.
\end{abstract}

PALAVRAS-CHAVE: 1968; Revolução Cultural; Memória; Direitos Humanos.

\section{THE YEAR THAT HAS NOT ENDED: FROM THE IMAGINATION IN THE POWER OF EUROPE TO THE STATE OF EXCEPTION IN BRAZIL}

\begin{abstract}
The article addresses the emblematic year of 1968 as a year of movements and contestations that marked a whole generation of young people. The 1968 demonstrations stirred Europe, reverberated in various parts of the world, including Brazil. The first part of this approach portrays the movement in Paris as a stage of the great manifestations of a true cultural revolution. The second part deals with the demonstrations in Brazil, the year in which we lived a true State of exception. Even with this political condition, the young people took to the streets and showed their indignation. It was a year of asking for imagination in power in Europe and in Brazil the pinnacle of a military civilian dictatorship. It was a period of contrasts, so emblematic. The great legacy of 1968 fifty years later is to revive a memory that still lives, that has marked generations and that it is worth remembering it for the courage and daring of the students in the constant struggle for human rights.
\end{abstract}

KEYWORDS: 1968; Cultural Revolution; Memory; Human Rights.

\footnotetext{
${ }^{1}$ Doutor em História Social pela Universidade Federal Fluminense (UFF). Pesquisador associado da UNESCO. Docente do Curso de Mestrado em Direitos Humanos da Universidade Regional do Noroeste do Estado do Rio Grande do Sul (UNIJUÍ).

${ }^{2}$ Mestranda em Direitos Humanos na Universidade Regional do Noroeste do Estado do Rio Grande do Sul (UNIJUÍ).

3 Mestrando em Direitos Humanos no Programa de Pós-graduação stricto-sensu em Direito da Universidade Regional do Noroeste do Estado do Rio Grande do Sul (UNIJUÍ).
} 


\section{EL AÑO QUE NO ACABÓ: DE LA IMAGINACIÓN EN EL PODER EN EUROPA AL ESTADO DE EXCEPCIÓN EN BRASIL}

RESUMEN: El artículo aborda el emblemático año de 1968 como un año de movimientos y contestaciones que marcaron a toda una generación de jóvenes. Las manifestaciones de 1968 agitaron la Europa, repercutieron en varias partes del mundo, incluso en Brasil. La primera parte del enfoque retrata el movimiento en París como un escenario de las grandes manifestaciones de una verdadera revolución cultural. La segunda parte aborda las manifestaciones en Brasil, en el año en que vivíamos un verdadero Estado de excepción. Incluso con esa condición política, los jóvenes acudieron a las calles y mostraron su indignación. Fue un año de pedir imaginación en el poder en Europa y en Brasil el auge de una dictadura civil militar. Fue un período de contrastes, por eso emblemático. El gran legado de 1968 cincuenta años después es de revivir una memoria que todavia permanece viva, que marcó generaciones y que vale recordarle por el coraje y osadía de los estudiantes en la lucha constante por los derechos humanos.

PALABRAS CLAVE: 1968; Revolución Cultural; memoria; Derechos Humanos.

\section{INTRODUÇÃO}

O maio de 1968 completou cinquenta anos em 2018 e continua sendo o ano que não acabou. Foi tão emblemático que merece ser rediscutido e reatualizado para que as novas gerações tenham noção do que ele realmente significou. Foi o que podemos definir de revolução cultural, pois mexeu nas bases de um mundo até então muito tradicional. Os valores tradicionais foram contestados, a velha forma de viver em sociedade foi duramente abalada. Os jovens de 1968 buscavam um novo modelo de vida, com mais liberdade de expressão, com mais ousadia para enfrentar o mundo capitalista. Era preciso reivindicar uma nova forma de expressão, com mais imaginação, mais arte, mais humana e democrática. Os valores conservadores das sociedades europeia e norte-americana precisariam ser revistos. Os jovens buscavam uma forma de viver mais democrática e participativa, como eles mesmos diziam, a imaginação no poder, é proibido proibir, queriam mais liberdade e imaginação.

Os jovens estudantes foram os principais protagonistas de 1968 e contavam com o apoio de alguns movimentos sociais, mas foi essencialmente um movimento cultural, não marcado por um viés político-partidário. Os movimentos sociais que apoiaram o 
Maio de 1968 em Paris e em outras partes do mundo fizeram uma aproximação com os ideais dos jovens. Eles não pretendiam mudar as bases sociais; queriam uma nova forma de expressão, um sistema educacional mais democrático e menos tradicional, queriam inserção social numa sociedade capitalista marcada pelos valores de consumo. Procuraram nas artes uma forma de expressão, combatendo a massificação. As artes constituíram a base de comunicação, os estudantes de belas artes foram extremamente participativos, elaboraram cartazes que coloriram as ruas de Paris. Eles foram singulares em sua expressão, comunicavam com criatividade obtendo apoio de vários segmentos sociais. Os estudantes foram às ruas, levaram suas reivindicações por mais direito de participação e respeito a seus ideais.

Mas o que há de tão emblemático no ano de 1968 que cinquenta anos depois ele continua sendo lembrado e atualizado? O grande legado cultural desse ano foi, essencialmente, o modo de contestar tudo aquilo que incomodava as novas gerações, a tradição, o autoritarismo, as velhas formas de imposição do poder político. Tudo isso causava um mal-estar às novas gerações que buscavam sua inserção na sociedade. A importância de lembrar e ressignifcar o ano de 1968, constitui no fato de que muitas questões que foram contestadas naquele período ainda continuam abertas e as novas gerações ainda sentem o incomodo de viver em uma sociedade impositiva de valores conservadores. A liberdade de expressão sempre foi, de certa forma, controlada no espaço público. Os que ousam se manifestar ainda sofrem com a censura. O que atualmente se discute sobre a criminalização dos movimentos sociais é uma verdadeira forma de coerção e censura. $\mathrm{O}$ espaço público sempre foi alvo de censura por parte dos governos conservadores, que tentam controlar a expressão e mesmo criminalizar, tudo isso em nome de uma ordem social. Qualquer coisa que possa ameaçar essa ordem é motivo de censura, pois contestar as velhas formas de poder ainda continua sendo uma ousadia para poucos.

A complexidade de 1968 ainda é inexplicável, pois foi um ano de muitas mudanças em várias partes do mundo. As contestações começariam pelos países socialistas até chegar aos capitalistas. A primavera de Praga foi o impulso inicial, mostrando que mesmo no bloco socialista eram necessárias mudanças; era preciso dar uma cara humana ao socialismo. Mas nos países capitalistas o impulso foi ainda maior, 
1968 o ano que não acabou: da imaginação no poder na Europa ao estado de exceção no Brasil Ivo dos Santos Canabarro; Luane Flores Chuquel; Alef Felipe Meier

com repercussões mais acentuadas, pois as manifestações tomaram as ruas e praças, mobilizando os jovens nos espaços públicos. As mobilizações mostraram, num primeiro momento, o descontentamento das gerações mais jovens com as formas de poder em todas as instâncias, não era apenas o poder dos governantes, mas também os micropoderes ${ }^{4}$, as relações entre pais e filhos, professor e alunos, em todos os espaços que infligiam uma biopolitica ${ }^{5}$ nos corpos dos jovens. Foi preciso uma série de manifestações para mudar algumas perspectivas de controle social e de poder na sociedade da época, era um período de grande prosperidade econômica, porém com uma forma muito tradicional de poder e controle do Estado e das instituições. A sociedade capitalista permanecia com formas tradicionais de exercer o poder político e biopolítico; os espaços para a participação e a liberdade de expressão eram severamente controlados e, acima de tudo, combatidos.

Por ora este artigo está dividido em duas partes complementares; a primeira sobre o Maio de 1968 no mundo, com ênfase especial para as manifestações de Paris,

\footnotetext{
4 "Segundo Michel Foucault, há uma rede de micropoderes, de poderes centrífugos, locais, familiares e regionais, com uma variedade de conflitos, dotados de articulações horizontais, mas onde também surge uma articulação vertical, uma integração institucional dos poderes múltiplos tendente para um centro político, para um poder centrípeto. A sua teoria dos micropoderes, esboçada em L'Archéologie du Savoir, 1969, alcançou estruturação na obra Surveiller et Punir, de 1975. Entre esses vários micropoderes, importa salientar os chamados poderes difusos que actuam pela persuasão e pela sedução. É o caso do poder dos meios de comunicação social, dos mass media, dos suportes da difusão da comunicação, como é a imprensa, o rádio e a televisão, a quem já chamam o quarto poder. A actividade de todos estes grupos não se processa no vazio, mas antes dentro de um quadro estrutural e de acordo com certas regras do jogo. Há, com efeito, uma estrutura de rede (network structure), uma relação de relações, uma rede de micropoderes, um macrocosmos de macrocosmos sociais. Há um poder político, um campo concentrado, uma governação que trata de coordenar o processo de ajustamento entre os grupos, procurando um ponto de equilíbrio entre as tensões. Neste sentido, o Estado é perspectivado, não como uma coisa, mas como um processo relacional, entre a sociedade civil, ou comunidade, e o aparelho de poder, como o mero quadro estrutural de um jogo entre forças centrífugas e centrípetas, que constituiriam uma rede de micropoderes, locais, regionais, familiares, económicos e culturais, toda uma miríade de poderes periféricos, não necessariamente hierarquizáveis como corpos intermediários, que se justaporiam, de forma complexa, pelo que a soberania, na prática, seria divisível e, sobre o mesmo espaço e as mesmas pessoas, não teria que haver o centralismo e o concentracionarismo de uma única governação. O político é uma invenção marcada por uma estratégia que globaliza várias micro-estratégias, onde há uma especial forma de poder, o poder político, a síntese emergente, integrante de vários micropoderes, onde uma multiplicidade de actores actua numa determinada unidade, em quadros estruturais, em circuitos institucionalizados" (MALTEZ, s.a, s.p.).

5 "A biopolítica moderna provoca um alargamento progressivo da soberania para além dos limites do estado de exceção. Uma linha em movimento que se desloca cada vez mais para o controle da vida humana em que vigora a vontade soberana e reduz aquela a pura vida nua. Agamben chama atenção para a contradição que habita o próprio estado de direito que pensa ter abolido a vontade soberana quando na verdade ela permanece oculta, para ser utilizada quando for preciso, na figura jurídica do estado de exceção. Ainda Agamben mostra que na origem da política moderna, antes que os direitos do cidadão, está a captura política do corpo" (RUIZ, 2013b, p.15).
} 
1968 o ano que não acabou: da imaginação no poder na Europa ao estado de exceção no Brasil Ivo dos Santos Canabarro; Luane Flores Chuquel; Alef Felipe Meier

sendo ali o polo irradiador. Na segunda parte, perceber como esses movimentos repercutiram no Brasil, pois buscava a imaginação no poder num contexto social em que os atores sociais combatiam uma ditadura militar severa e repressiva. A primeira parte apresenta o Maio de 1968 como uma revolução cultural, exatamente nesse sentido do termo, cultural, pois as grandes reivindicações estavam mais ligadas ao universo da cultura. Não foi um movimento revolucionário que pretendesse mudar as estruturas da sociedade capitalista ou socialista. Os jovens reivindicavam questões que envolviam as suas vidas em uma sociedade tradicional, buscavam uma nova perspectiva mais democrática e participativa, com igualdade de direitos entre os gêneros, entre as diferenças de aceitação dos imigrantes, entre outras. Os protagonistas desses movimentos foram ousados; contestaram a ordem vigente, o autoritarismo e o tradicionalismo na educação, a falta da imaginação no poder e tudo o que poderia representar autoritarismo do Estado. O movimento tomou grandes proporções, algumas de forma mais direta nas ruas, e em outras de forma mais discreta, mas sempre com a intenção de questionar o tradicionalismo que marcava o período.

$\mathrm{Na}$ segunda parte, o enfoque está direcionado para as repercussões do Maio de 1968 no Brasil, como toda essa onda de manifestações atingiu nossa sociedade que vivia em plena ditadura militar. Se os jovens em Paris gritavam pela imaginação no poder, aqui no Brasil combatíamos a repressão do poder de Estado, um verdadeiro Estado de exceção ${ }^{6}$, em que tudo era proibido e reprimido. Mesmo num contexto político marcado pelo autoritarismo e repressão, aconteceram importantes manifestações no Brasil que repercutiram os ecos do Maio de 1968. O mais importante foi a passeata dos 100 mil no Rio de Janeiro, uma passeata liderada por estudantes, mas que teve o apoio de artistas, músicos, intelectuais que ousaram contestar num período de exceção. Foi um ano ímpar para a história do Brasil, no auge da repressão os jovens ousaram e contestaram a ditadura. O slogan, "proibido proibir" virou uma canção de Caetano Veloso, se existiu a repressão política, a arte se manifestou juntamente com os jovens. Aqui no Brasil os jovens foram os principais protagonistas nas ruas, protestaram

\footnotetext{
6 "Para Agamben, o estado de exceção é a norma das atuais democracias e está intimamente ligada às práticas de governo, que, por sua vez, estão ligadas ao governo da vida e a "normalização" [...]" (MARTINS, 2013, p.13).
} 
contra tudo aquilo que os reprimia. No final do ano de 1968, as manifestações foram ainda mais reprimidas com o decreto do AI-5, tendo nele a forma e o período mais autoritário da ditadura. O Brasil foi cenário da repressão, mas sempre com resistência, tanto no espaço público quanto nas manifestações das artes.

\section{É PRECISO IMAGINAÇÃO NO PODER: MAIO DE 1968 E SUAS REPERCUSSÕES}

Para pensar 1968, é necessário o entendimento do contexto socioeconômico daquele período, pois as questões que apareciam nas pautas dos protestos repercutiam as formas de poder estabelecidas no período. As pessoas viviam em um mundo bipolarizado entre capitalistas e socialistas, muitas das rivalidades do período eram decorrentes dessa divisão do mundo em blocos. O bloco capitalista estava em ascensão, nunca havia até aquele momento histórico um crescimento tão grande, o que se iniciou logo após o fim da Segunda Guerra Mundial. A partir de 1945, os países capitalistas conquistaram uma taxa de crescimento extraordinário. Pode-se observar que na Europa ocidental, a renda per capita chegaria a um índice de aproximadamente cinco por cento ao ano, e isso se estendia a muitos outros países capitalistas. No caso do Japão chegou até a oito por cento ao ano. Era um crescimento extraordinário, o desemprego praticamente não existia nos países capitalistas desenvolvidos. Esse período que compreende entre 1945 até a década de $1970^{7}$ foi considerado como uma verdadeira "Era de Ouro do capitalismo".

Se por um lado vivíamos a era de ouro do capitalismo, de outro lado, os problemas sociais convergiam para incitar mudanças de comportamento, experimentávamos um certo mal-estar em meio a esta prosperidade. A sociedade global passava por momentos de tensão, basta citar o caso da Guerra Fria, opondo-se de um lado os EUA e de outro a então União Soviética, as tensões estavam postas, era o começo das grandes manifestações que pediam a paz mundial e a representatividade na cena política. A tensão foi aumentando com o passar do tempo, aconteceram vários protestos mundo a fora contra a Guerra do Vietnã, contra a morte do líder negro norte

\footnotetext{
${ }^{7} \mathrm{O}$ desenvolvimento do capitalismo e de seus conflitos no século XX pode ser melhor analisado, a partir de uma perspectiva política e econômica na obra de Hobsbawm (1995).
} 
1968 o ano que não acabou: da imaginação no poder na Europa ao estado de exceção no Brasil Ivo dos Santos Canabarro; Luane Flores Chuquel; Alef Felipe Meier

americano Martin Luther King, da emblemática Primavera de Praga, do massacre dos estudantes no México. No caso brasileiro, em plena ditadura militar, os atos contra a morte do estudante Edson Luís que comoveu o Rio de Janeiro e o movimento estudantil brasileiro. $\mathrm{O}$ mundo estava em ebulição, ocorriam protestos em vários países. Todos reivindicavam participação no cenário político e respeito às diferenças sociais.

É extremamente emblemático começar pela Primavera de Praga, que aconteceu na então Tchecoslováquia. Foi um movimento que reivindicava um socialismo com rosto humano. Esse movimento serviu para mostrar para os ideólogos do socialismo que a população não aceitava ser tratada com uma simples massa, buscava a subjetividade de cada membro da população, sujeitos com direitos que buscavam autonomia num regime político também totalitário. A Primavera de Praga na Tchecoslováquia foi liderada naquele ano pelo primeiro-ministro Alexander Dubcek ${ }^{8}$, o qual foi derrotado pelas tropas do Pacto de Varsóvia. O resultado dessas manifestações foi a sua total repressão. A Primavera de Praga foi emblemática para as pessoas que viveram naquela época, mas seu resultado final foi a ocupação soviética que durou praticamente vinte e cinco anos.

Mas o Maio de 1968 teve maior repercussão em Paris, palco das maiores contestações, onde estudantes e os movimentos sindicais fizeram os maiores protestos, trazendo à cena política também os imigrantes que não tinham nenhuma participação política no cenário francês. A organização dos estudantes franceses começou na Universidade de Nanterre, muito próximo a Paris, lá foi o embrião de toda a movimentação que ocuparia as ruas nos meses seguintes. Pouco tempo depois os estudantes tomaram as ruas de Paris e começariam as suas manifestações que repercutiram em vários outros países do mundo. Um estudante francês de sociologia, Daniel Cohn-Bendit ${ }^{9}$, começaria a organização dos movimentos na capital onde tomaram as ruas com violentos confrontos com a polícia, resultando em centenas de

\footnotetext{
8 A atuação de Alexander Dubcek, pode ser percebida em obras posteriores como também em uma recente revisão sobre o maio de 1968. Nessa reportagem, da folha de São Paulo, aparece com evidência a sua atuação nos movimentos da Primavera de Praga. Disponível em: < https://www1.folha.uol.com.br/folha/mundo/ult94u396937.shtml>. Acesso em: 23 Agos. 2018, 07:32:11.

${ }_{9}^{9}$ Pode-se encontrar várias entrevistas com Daniel Cohn-Bendit, tanto no exterior como, inclusive, aqui no Brasil. Destaca-se a entrevista de Daniel com Pedro Bial, na qual ele destacou todo o seu envolvimento nos acontecimentos de maio de 1968. Disponível em: < https://veja.abril.com.br/entretenimento/ter-sidoexpulso-da-franca-me-salvou-diz-cohn-bendit-a-bial/>. Acesso em: 23 Agos. 2018, 09:22:01.
} 
1968 o ano que não acabou: da imaginação no poder na Europa ao estado de exceção no Brasil Ivo dos Santos Canabarro; Luane Flores Chuquel; Alef Felipe Meier

feridos nos ataques contra a repressão policial. A Universidade de Sorbonne em Paris foi um dos centros irradiadores dos movimentos, a partir de então ela mudaria radicalmente a sua forma de ensino e relação entre professores e alunos.

Os estudantes tomaram as ruas de Paris. Eram manifestações dia a dia, muitos trabalhadores e sindicatos aderiram às greves, mas não tinha um caráter partidário, pois os estudantes protestavam contra o capitalismo e contra o comunismo. Não queriam mudar o mundo, não tinham um grande projeto de mudanças sociais, era o que se poderia chamar de revolução cultural. Segundo o depoimento do próprio Cohn-Bendit, era uma certa espontaneidade incontrolável, eles queriam participação em tudo, mudar as regras do poder, queriam construir novas redes e alianças, contando com a participação de trabalhadores e imigrantes, esses últimos sempre rejeitados dos/nos projetos políticos de inclusão social. Os estudantes criariam as suas palavras de ordem para as manifestações, como exemplo: seja realista peça o impossível; a barricada fecha a rua, mas abre o caminho; é proibido proibir. Essas, funcionavam como slogans e eram usadas durante todo o movimento, o que influenciou jovens de outras partes do mundo, inclusive no Brasil.

Imagem 01: Estudantes nas ruas do Bairro Quartier Latin nos protestos de 1968, em Paris

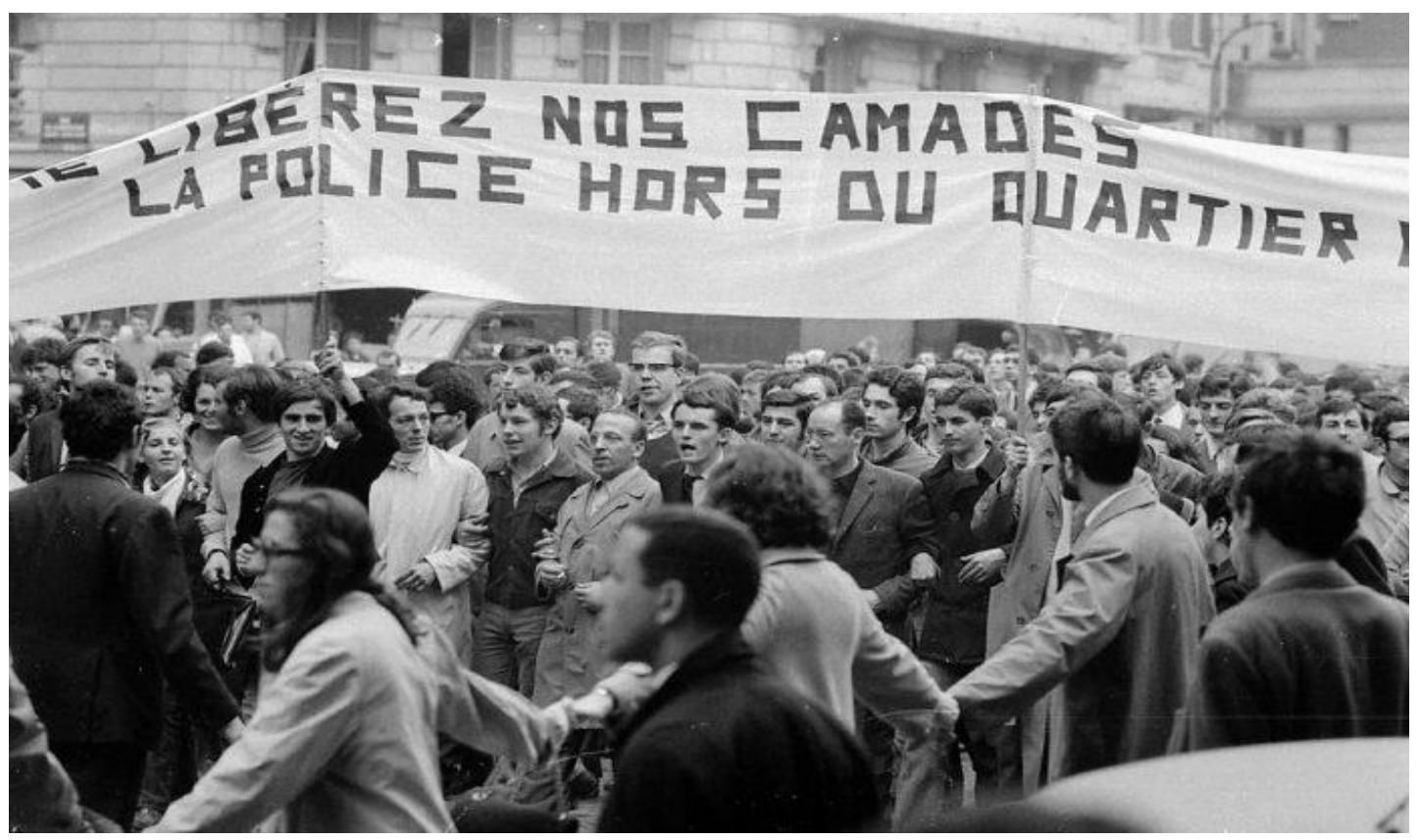

Fonte: Reprodução Facebook (http://www.paginab.com.br/cultura/50-anos-de-maio-de-1968/). 
1968 o ano que não acabou: da imaginação no poder na Europa ao estado de exceção no Brasil Ivo dos Santos Canabarro; Luane Flores Chuquel; Alef Felipe Meier

Os jovens estudantes e simpatizantes que foram às ruas fizeram uma verdadeira revolução comportamental, longe de ser uma revolução política partidária ou de blocos, pois não era esse o objetivo das manifestações. Todas as formas de organização dos jovens tinham como alvo principal a contestação das formas de poder opressor às quais estavam submetidos. Contestavam todas as instituições: as universidades, as escolas, os princípios de autoridade, mas não era uma luta apenas no espaço público; queriam transformações no espaço privado, como as mudanças nas relações familiares e sexuais. Também questões muito particulares de comportamento e estilo, como o tipo de roupas que desejavam usar, o corte de cabelo adequado a sua geração. Combatiam o comportamento consumista que o capitalismo em ascensão impunha aos jovens.

Os movimentos de Maio de 1968 repercutiram a partir de Paris para outras partes do mundo, mas foi ali o palco dos grandes acontecimentos. Os jovens não seguiam doutrinas partidárias, o que levou a um certo estranhamento dos partidos políticos. O próprio PCF (Partido Comunista Francês) manteve-se distante das manifestações por dois motivos essenciais: primeiro porque o movimento começou com a Primavera de Praga, com uma orientação socialista, o que, de certa forma, contestava os princípios dos partidos comunistas; segundo, porque os movimentos não tinham um viés de contestação de mudança da sociedade, típicas dos partidos comunistas. Sendo assim, a classe operária não se aliou aos jovens estudantes, pois não havia um projeto de profundas mudanças no cenário político; era um projeto de mudanças nos padrões de comportamento, ou seja, uma revolução cultural.

Destacaram-se as organizações baseadas em redes, ao contrário de outras com nomes de grandes líderes políticos. Os jovens estudantes eram os protagonistas que ocuparam as ruas e as universidades. As manifestações nas ruas de Paris foram duramente combatidas pela polícia, muitos manifestantes foram reprimidos, pois ameaçavam a ordem vigente. Mas foi uma revolução pacífica em Paris, em outros lugares foi mais combatida como por exemplo no México onde vinte e seis estudantes foram mortos. Em Paris houve alguns estudantes feridos e um morto, por isso foi considerada como uma revolução pacifica. Isso se deve principalmente à origem dos movimentos, sem uma intervenção direta dos partidos políticos, os quais eram mais agressivos e também combatidos. Eram movimentos mais autônomos sem a presença 
1968 o ano que não acabou: da imaginação no poder na Europa ao estado de exceção no Brasil Ivo dos Santos Canabarro; Luane Flores Chuquel; Alef Felipe Meier

dos grandes líderes políticos. Os partidos viram que os estudantes tinham uma autonomia na busca de suas causas. Os estudantes representaram na década de 1960 um exemplo de organização de luta. Os especialistas políticos chamam isso de redes horizontais, ou seja, sem a necessidade de um centralismo partidário, ou mesmo de sindicatos e de seus líderes para comandar os movimentos. Destacam assim um outro protagonismo dos jovens que lutavam por questões de seu mundo, de suas necessidades, de suas utopias e de sua imaginação no poder.

O caso do México ${ }^{10}$ foi atípico, pois houve violência, foi um episódio menos conhecido no qual os estudantes críticos ao governo foram mortos em outubro de 1968. Os assassinatos ocorrem em uma das principais praças a de Tlatelolco dias antes dos Jogos Olímpicos na Cidade do México. O episódio repercutiu muito, pois todas as manifestações de 1968 na Europa foram mais pacíficas, com poucos confrontos com a polícia. O caso do México foi singular. As manifestações em Paris ocorriam com certa tranquilidade, houve sim confrontos com a polícia, mas não se chegou a casos alarmantes. Estudantes parisienses foram reprimidos nas ruas, pois representavam uma ameaça à ordem estabelecida na cidade, como também em outras partes do mundo. No Brasil, os movimentos foram duramente reprimidos pela polícia da ditadura militar, algo que vamos ver no segmento desse texto.

Os estudantes que foram às manifestações em 1968 eram ousados, não tinham medo dos perigos que enfrentavam. Eles foram protagonistas em várias partes do mundo, no EUA, no Japão, no México, na Tchecoslováquia, na França, no Brasil, enfim em todos os lugares lutavam contra a opressão do Estado. Combateram todas as formas de autoritarismo, tanto no capitalismo quanto no socialismo. Queriam um mundo mais igualitário entre os diversos segmentos que compõem a sociedade política, por isso estavam ao lado dos imigrantes que eram discriminados. Combatiam todas as desigualdades, as ditaduras e as guerras. Tinham uma utopia, o desejo de um mundo melhor, mais igualitário, acreditavam que uma sociedade sem utopia estava condenada à

\footnotetext{
${ }^{10} \mathrm{O}$ caso do México foi realmente atípico, com uma violência extrema, ou seja, com a morte de muitos estudantes que protestavam naquele 1968. Em outros países a violência foi de certa forma controlada. Pode-se perceber no artigo seguinte mais detalhes sobre o que realmente aconteceu no México. Disponível em: <https://periodicos.ufpe.br/revistas/revistaclio/article/viewFile/24192/19631>. Acesso em: 23 Agos. 2018, 09:33:12.
}

Fronteiras: Revista de História | Dourados, MS | v. 20 | n. 36 | p. 154-176 | Jul. / Dez. 2018 
1968 o ano que não acabou: da imaginação no poder na Europa ao estado de exceção no Brasil Ivo dos Santos Canabarro; Luane Flores Chuquel; Alef Felipe Meier

ruina. Esse sentimento é o que mantém até hoje vivo os ideais de 1968, com o desejo utópico de um mundo melhor.

Em Paris os estudantes das belas artes demonstraram com clareza todo o seu desejo utópico, pois foi exatamente a Escola de Belas Artes a verdadeira usina de ideias, o palco dos grandes acontecimentos. Os estudantes usaram a arte como um instrumento de luta, produzindo cartazes, poemas e slogans que tomariam conta da cidade de Paris. Os muros da cidade foram escolhidos para se colocarem os cartazes com imagens e slogans. Isso gerou a reação da polícia, que, além de conter as manifestações das ruas se ocupava em arrancar os cartazes dos muros. Os cartazes foram tão emblemáticos, tanto que muitas pessoas os arrancavam e os guardavam para negociar futuramente. Eles formaram um verdadeiro tesouro iconográfico, pois as editoras queriam comprá-los para fazer publicações. Os cartazes representaram uma aproximação entre a arte e a revolução, imagens de um período revolucionário de encontro entre as diversas formas de manifestações.

\section{E O ESTADO DE EXCEÇÃO NO BRASIL}

O ano de $1968^{11}$ nos parece um paradoxo a ser desvendado atualmente, pois, se de um lado na Europa se clamava pela imaginação no poder, pela liberdade de expressão, no Brasil se vivia um dos momentos de maior fechamento político e de privação de liberdades individuais, um típico estado de exceção. Foi um ano emblemático em todos os sentidos, parecia uma nova forma de expressão individual e coletiva, um momento de muitos protestos que marcou o fim de um período de austeridade na Europa e o começo do extremismo autoritário no Brasil. Um paradoxo entre dois continentes que viviam fases distintas na forma de aplicação do poder. Era muito difícil no Brasil lutar pela imaginação no poder exatamente quatro anos depois do início de uma das ditaduras militares mais violentas da América do Sul.

Se por um lado, na Europa, os movimentos sociais emergiram de forma espetacular nesse período, eram movimentos de trabalhadores, de estudantes, de

\footnotetext{
${ }^{11}$ O paradoxo do ano de 1968 pode ser melhor analisado na obra de Zuenir Ventura (1988), que aborda a problemática de uma forma quase literária, foi um livro de repercussão no Brasil tanto sobre esse contexto de ebulição na Europa quanto do fechamento político no Brasil.
} 
1968 o ano que não acabou: da imaginação no poder na Europa ao estado de exceção no Brasil Ivo dos Santos Canabarro; Luane Flores Chuquel; Alef Felipe Meier

mulheres, ou de causas específicas, como os ligados à ecologia, às questões étnicas, enfim de diferentes formas de representabilidade. Esses movimentos cada vez mais, conquistavam a população que se sentia representada por eles, seja por questões ideológicas, de gênero, de lutas em comum ou de alguma simpatia com o povo que se mostrava disposto a apoiar alguma mudança social. Por outro lado, os próprios Estados sentiam a pressão da população pelas reformas em seu interior, não era mais possível governar de forma autoritária e centralizadora em regimes democráticos e com participação social. Os governantes europeus sentiam que o povo não queria mais o velho estilo de poder do Estado, pois lutava pela incorporação de novos direitos sociais nos processos políticos e essencialmente uma nova forma de administrar o poder.

O paradoxo estava instaurado em 1968. Parecia mais fácil pedir a imaginação no poder e reformas políticas em países de regime democráticos, mas no caso do Brasil, isso se revelou complicado. A ditadura militar e civil que começou em março de 1964 chegaria até 1968 ainda mais fechada e autoritária, administrada por meio de Atos Institucionais, que se sobrepunham a própria Constituição, concediam amplos poderes ao governo passando por cima do Congresso e dos Partidos Políticos. O ano de 1968 foi emblemático pois com a instalação do AI5 - Ato Institucional número 5 - a ditadura mostrou o seu lado mais autoritário e repressivo, foi o ato que mais repercutiu na sociedade civil, pois acabava com a liberdade individual, suprimindo os próprios direitos humanos, ou seja, permitindo a violação destes de forma sistemática e legitimada pelos mecanismos do Estado. A ditadura militar mostrou seu lado mais violento e centralizador com o AI5, permitindo a violência dentro do próprio Estado ${ }^{12}$ o cidadão perderia sua liberdade em nome de um projeto de governo alicerçado no controle social e político de toda a população brasileira.

A presença dos Atos Institucionais durante a ditadura militar brasileira foi constante e suas repercussões atestam a perspectiva do centralismo do poder nas mãos

\footnotetext{
12 Para uma leitura mais demonstrativa pode-se consultar Elio Gaspari (2002) e Caroline Silveira Bauer (2012), ambos apresentam uma discussão sistematizada sobre os rumos da ditadura militar no Brasil, concebidos com novas referências sobre o autoritarismo, esses autores inovam na abordagem sobre o tema.
} 
1968 o ano que não acabou: da imaginação no poder na Europa ao estado de exceção no Brasil Ivo dos Santos Canabarro; Luane Flores Chuquel; Alef Felipe Meier

do presidente da República. Logo no primeiro ano da ditadura foi instituído o AI- ${ }^{13}$, em abril de 1964, estabelecendo a eleição do novo presidente da República pelo Congresso Nacional, sendo uma votação indireta o que limitou o poder sem a participação popular. Este Ato Institucional teve abrangência em todos os segmentos da política e nos próprios rumos da economia do país, visando reformar todo o sistema econômico capitalista aliando-se automaticamente ao capital externo para financiar o desenvolvimento nacional, o governo e apoiadores denominaram isso de modernização na economia. Tinha também uma finalidade política específica que era o constante combate ao comunismo, o qual era visto como uma grande ameaça à política do país. $\mathrm{Na}$ economia as intenções foram também emergentes lançando o PAEG (Plano de Ação Econômico do Governo).

A partir do AI-1 as medidas políticas, econômicas e sociais foram as mais rígidas possíveis, como uma forma de garantir a legitimidade do poder dos militares. Em consequência as classes trabalhadoras foram as mais atingidas (Cf.: BORIS, 1995, p. 470). Ainda em 1964 foi estabelecida a lei da greve, o que se tornou quase impossível a realização de paralisações legais no Brasil. Quanto aos direitos dos trabalhadores de imediato foi determinado o fim da estabilidade do trabalho, o que vigorava para trabalhadores com mais de dez anos de serviço, era uma garantia da CLT (Consolidação das Leis do Trabalho). Com esse Ato Institucional os militares garantiram a implantação de um regime autoritário, com o comando dos militares que centralizavam todo o poder. Os civis no governo tinham um papel secundário, eram mais apoiadores do que mandatários. A luta contra o comunismo tornou-se uma bandeira dos militares, era quase que um inimigo oculto que deveria ser combatido por toda a sociedade. Criara-se todo um imaginário que colocava os comunistas como traidores da pátria.

Em 1965, no governo de Castelo Branco foi editado o AI-2, logo após as eleições, pois ele não ficou satisfeito como o resultado do que aconteceu nos Estados (BORIS, 1995, p. 474). Esse Ato Institucional estabelecia definitivamente a eleição do presidente e vice-presidente da República pela maioria absoluta do Congresso Nacional,

\footnotetext{
13 Segundo Boris Fausto (1995) essa questão dos Atos Institucionais eram uma forma de evitar que o governo sofresse alguma forma de contestação, pois os mesmos garantiam a plena aplicabilidade de um poder de decisão mesmo acima da Constituição.
} 
o qual seria, por muitos anos, manipulado pelos mesmos militares, a votação seria em sessão pública e nominal. Queriam prevenir surpresas que não estariam ao seu controle. O AI-2 centralizou ainda mais o poder nas mãos do presidente da República, pois, a partir de então o mesmo poderia baixar atos complementares ao referido ato, bem como novos Decretos-Lei para garantir a segurança nacional. Mas uma das medidas mais evidente do AI-2 foi a extinção dos partidos políticos, pois os militares achavam que o pluripartidarismo era responsável pelas crises políticas. O mesmo ato deliberou apenas a existência de dois partidos políticos, no caso especifico, a ARENA (Aliança Renovadora Nacional) e MDB (Movimento Democrático Brasileiro). O primeiro era o partido dos militares e civis que os apoiavam, e o segundo era uma "possível” oposição, ou seja, o que era possível no momento político fazer alguma oposição ao regime militar.

O AI-3 foi mais específico, pois deliberou o princípio de que deveria haver eleições indiretas também para os governadores dos Estados, as mesmas deveriam ser feitas pelas respectivas Assembleias Estaduais (BORIS, 1995, p. 474). Este ato permitiu uma interferência direta do governo federal nos Estados, ele garantia a coesão política com o controle dos mecanismos representativos da população. Em 1967, foi criada uma nova Constituição, a primeira ao modelo militar de governo. Houve alguns embates políticos com a crítica do MDB. No fim do ano de 1966, em pleno trabalho do texto constitucional, o Congresso foi fechado, como resposta o governo federal baixou o AI4, que tratou de uma medida de reunião extraordinária com o propósito de aprovar a nova Constituição (BORIS, 1995, p. 475). Com a nova Constituição de 1967, o Executivo ampliou ainda mais os seus poderes, permitindo também a cassação de mandatos e a gradual perda de direitos políticos.

O contexto político de 1968 no Brasil repercutiu nos movimentos que estavam acontecendo na Europa. Foi realmente um ano ímpar com a oposição dos jovens, trabalhadores e mulheres que ousavam sonhar com um mundo melhor. Esta onda de movimentos repercutiu também nos Estados Unidos, havendo manifestações contra a Guerra do Vietnã, mas o grande impacto foi mesmo na Europa onde as mobilizações tomaram as ruas. Na França, os movimentos foram constantes, a luta inicial era pela transformação do sistema de educação, queriam acabar com o formalismo nas escolas e 
1968 o ano que não acabou: da imaginação no poder na Europa ao estado de exceção no Brasil Ivo dos Santos Canabarro; Luane Flores Chuquel; Alef Felipe Meier

universidades. As manifestações foram tantas que, de certa forma, afetaram o governo de De Gaulle. O movimento das mulheres naquele país foi intenso também buscando liberação sexual e afirmação dos direitos das mulheres. Todos esses movimentos na Europa e nos Estados Unidos repercutiram no mundo inteiro, pois visavam transformar as formas políticas tradicionais que estavam superadas. O grande slogan era a “imaginação no poder”.

O clima de mudanças de $1968^{14}$ impactou de forma decisiva na cultura brasileira. As artes plásticas, a música, o teatro, o cinema, enfim o contexto cultural sofreu alterações. Os artistas cada vez mais engajados na luta pela garantia dos direitos humanos, tentaram na medida do possível para o momento, lutar contra um regime de ditadura militar. Muitos artistas, cantores, intelectuais tiveram que deixar o Brasil, pois tinham uma arte de consciência o que ameaçava os militares. Era o começo do exílio político. Mas as grandes manifestações aconteceram mesmo nas ruas do Brasil. O povo saiu para protestar contra a ditadura. Um dos acontecimentos que repercutiu nacionalmente foi a morte do estudante secundarista Edson Luis, morto pela Polícia Militar durante um protesto no Rio de Janeiro. Protestavam contra a péssima qualidade da alimentação fornecida aos estudantes pobres. A missa e o enterro do jovem foram realizados na Igreja da Candelária, sendo acompanhado por milhares de pessoas, causando grande comoção e indignação com a violência contra os que protestavam por qualquer motivo político.

Imagem 02: O funeral de Edson Luis

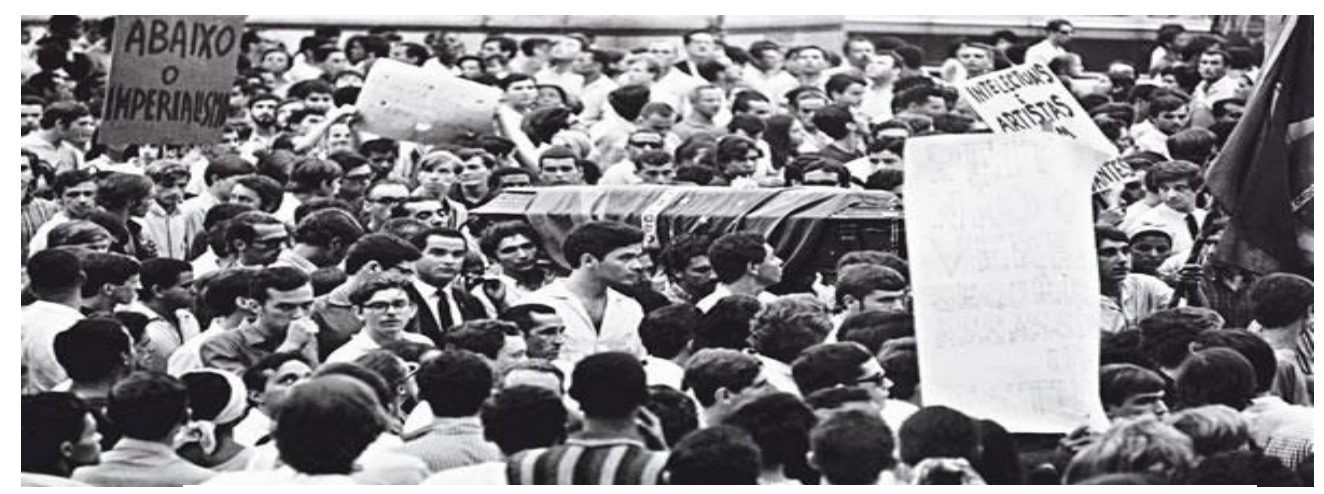

Fonte: https://www.revistaforum.com.br/edson-luis-50-anos-do-tiro-da-impunidade/

\footnotetext{
${ }^{14}$ Para uma discussão mais sistemática convém a leitura da obra de Zuenir Ventura (2006), pois o autor viveu o momento histórico e escreveu segundo suas experiências naquele ano de 1968, seu livro é resultado de vivências e observações.
}

Fronteiras: Revista de História | Dourados, MS | v. 20 | n. 36 | p. 154-176 | Jul. / Dez. 2018 
1968 o ano que não acabou: da imaginação no poder na Europa ao estado de exceção no Brasil Ivo dos Santos Canabarro; Luane Flores Chuquel; Alef Felipe Meier

O auge de 1968 no Brasil foi a denominada passeata dos 100 mil realizada no dia 25 de junho do mesmo ano. Foi uma grande mobilização nacional reunindo estudantes, segmentos representativos da igreja e da classe média. Aconteceu no Rio de Janeiro, palco das grandes mobilizações. Foi a maior passeata até aquele momento no Brasil, teve repercussão no mundo todo, pois mostrou que o país estava mobilizado em movimentos sociais e atento às questões que abalaram o mundo neste ano. A classe trabalhadora mostrou a sua força de mobilização, realizando greves gerais em vários estados brasileiros, pode-se citar a de Contagem perto de Belo Horizonte e a de Osasco na Grande São Paulo. Essas duas grandes greves criaram um clima de protestos de operários em todo o país, mas foram duramente combatidas pelos militares. Os militares agiam muito rapidamente nas greves com medo de que as mesmas tomassem uma proporção nacional, por isso colocavam toda a polícia e o aparato militar nos locais das greves fazendo intervenções com muita violência contra os trabalhadores. Convém salientar ainda a luta armada organizada no Brasil para combater a ditadura militar. Um dos grandes guerrilheiros foi a figura de Carlos Marighella, que comandou a luta nos movimentos revolucionários. A ditadura o considerou o inimigo número um da nação, não deu trégua até conseguir matá-lo, era uma questão de honra sua morte para os militares.

As manifestações de 1968 causaram impacto na opinião pública, pois mostrou claramente o projeto da ditadura militar no Brasil, a repressão foi intensa nas manifestações. Seguindo o que acontecia na Europa e Estados Unidos, a população brasileira clamou por democracia num contexto marcado pelo autoritarismo de Estado. O golpe fatal aconteceu no fim de 1968 no Brasil, quando o presidente Costa e Silva, no dia 13 de dezembro, decretou o AI-5, com respaldo do $43^{\circ}$ CSN (Conselho de Segurança Nacional) (BORIS, 1995, p. 480). Como primeira medida, fechou o Congresso, centralizando todo o poder em suas mãos. O AI-5 ${ }^{15}$ é considerado por historiadores e cientistas políticos como a revolução dentro da revolução, ou como se diz atualmente, a contra-revolução. Dentro da contra-revolução ocorreu o extremo do

\footnotetext{
${ }^{15}$ Segundo Schwarcz (2015) o AI-5 foi proclamado no Brasil na noite de 13 de dezembro de 1968, com discursos do ministro da justiça na época Gama e Silva que discursou durante cinco minutos e depois passou a palavra para Alberto Curi que discursou solenemente o texto do AI-5 para toda a sociedade brasileira, $\mathrm{O}$ documento contava com doze artigos e vinha acompanhado pelo Ato Complementar $\mathrm{n}^{\circ} 38$ que fechava o Congresso Nacional por tempo indeterminado.
} 
1968 o ano que não acabou: da imaginação no poder na Europa ao estado de exceção no Brasil Ivo dos Santos Canabarro; Luane Flores Chuquel; Alef Felipe Meier

centralismo do poder, o que se pode chamar de Estado de Exceção. Esse ato não tinha prazo determinado para acabar, ele durou até 1979, foram praticamente 10 anos de vigência do mesmo, até se chegar a uma possível abertura política. O presidente da República teria poder de fechar provisoriamente o Congresso, quando ele achasse necessário para não interferir em suas decisões políticas. $\mathrm{O}$ presidente tinha também o poder para caçar mandatos e suspender direitos políticos, bem como demitir ou aposentar servidores públicos.

Imagem 03: Jornalistas na Passeata dos Cem Mil. Rio de Janeiro, 1968

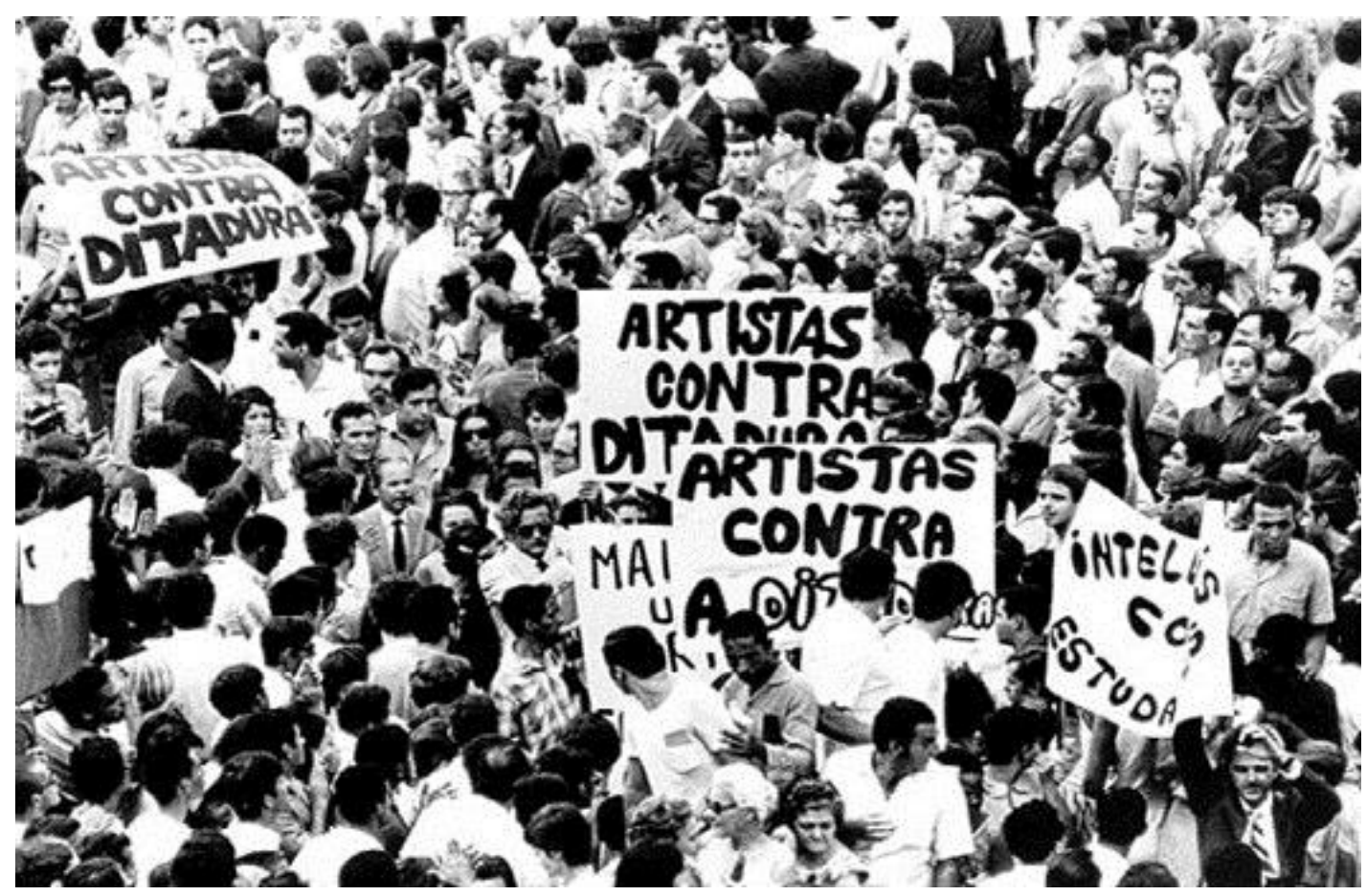

Fonte: Foto de Evandro Teixeira, https://joaquimlivraria.files.wordpress.com/2012/04/100mil6

O AI-5 tinha amplos poderes, diga-se que até mais que a própria Constituição militar de 1967. Ele interferiu plenamente na vida da sociedade civil, pois suspendeu direitos políticos conquistados há muito tempo. Um dos exemplos a ser citado é a questão da suspensão do habes corpus aos acusados de crimes políticos e nas infrações contra a ordem econômica e social. Foi o extremismo da interferência do poder do Estado na jurisprudência de um país. Poderia também confiscar bens materiais de pessoas acusadas como perigosos à nação. Os militares cada vez mais criavam 
1968 o ano que não acabou: da imaginação no poder na Europa ao estado de exceção no Brasil Ivo dos Santos Canabarro; Luane Flores Chuquel; Alef Felipe Meier

mecanismos para se protegerem dos crimes que faziam; criaram o que eles chamavam de "comunidade de informações" para dar legitimidade e proteção às figuras políticas e às instituições, responsáveis pela repressão, pelas torturas e desaparecimentos de pessoas consideras ameaças à ordem pública. Todo esse aparato de proteção era em nome da doutrina de segurança nacional, a qual legitimava qualquer ação de repressão pelos militares e civis a serviço do Estado. Com essas ações foram intensificados os processos de cassação de direitos políticos e expulsão de funcionários públicos, com foco nos professores universitários que poderiam ameaçar a ordem vigente.

Como esse ato, a censura instalou-se definitivamente nos meios de comunicação, jornais, rádios, televisão, revistas, teatro e artes em geral, isso restringiu o trabalho de jornalistas, escritores e artistas. Os meios de comunicação ficaram atrelados a censura que restringia os conteúdos que poderiam representar alguma ameaça à legitimidade do governo, com isso muitos jornalistas e escritores não conseguiam publicar seus artigos e livros. Na televisão, muitas novelas foram censuradas por apresentar algum tipo de crítica àquilo que era considerado a ordem pública. $\mathrm{O}$ teatro sofreu com a censura, pois havia vigilância in loco para ver o conteúdo de suas peças. A música popular brasileira foi duramente atacada, muitos cantores foram impedidos de gravar músicas ou mesmo cantá-las em festivais e shows. Alguns mais engajados politicamente foram exilados para outros países que davam maior liberdade de expressão. O exílio também foi uma alternativa para professores universitários e intelectuais descontentes com os rumos da ditadura militar. A luta armada foi um dos principais alvos da ditadura, pois ela representava uma forma de desestabilizar o regime em sua integridade centralizadora. Os membros da luta armada foram perseguidos, presos e, inclusive, mortos em nome do regime político. O AI-5 representou o auge da ditadura no Brasil foram anos de chumbo, mesmo assim muitos lutaram bravamente pela liberdade.

As repercussões do AI-5 no Brasil foram as mais variadas possíveis. De um lado, os militares que garantiam a centralização do poder, praticando perseguições, prisões, coerções, torturas, desaparecimentos e mortes. Por outro lado, a sociedade brasileira, que estava influenciada pelas grandes manifestações mundiais pela reforma nas instituições estatais. Acabaram os sonhos de imaginação no poder, começariam os 
1968 o ano que não acabou: da imaginação no poder na Europa ao estado de exceção no Brasil Ivo dos Santos Canabarro; Luane Flores Chuquel; Alef Felipe Meier

anos de chumbo, o auge da repressão do Estado. Esse ato e as demais medidas editadas posteriormente só afirmaram o poder dos militares no controle da ditadura. Alguns civis os apoiavam bem como parte da população brasileira que temia o comunismo. Os planos econômicos começariam a surtir efeitos. Em nome do desenvolvimento nacional, o governo buscou nos empréstimos externos uma foram de captar recursos para grandes obras de infraestrutura para alavancar um crescimento econômico baseado no capitalismo externo. Isso gerou para alguns segmentos da população uma certa confiança que aquela seria uma forma de governo capaz de desenvolver planos de crescimento do país. O poder cada vez mais centrado no Executivo era um governo com mãos de ferro, tudo dependeria de sua aprovação.

1968 foi, como parafraseia Zuenir Ventura, o ano que não terminou, exatamente pelo paradoxo estabelecido, os contrastes entre as democracias e as ditaduras, estavam em plena vigência no mundo a garantia dos direitos humanos. O AI5 no Brasil feriu duramente a garantia dos direitos humanos. As pessoas perderam seus direitos já conquistados e começaram a viver sob a tutela de um Estado autoritário, que pratica nas suas instituições a tortura e a morte. Tudo acontecia no interior do próprio Estado, os torturadores eram geralmente militares, mas alguns civis também trabalhavam nessas instituições, era uma forma de reprimir com a vida das pessoas. Muitos foram torturados, mortos e sepultados em covas coletivas nos cemitérios clandestinos para que os familiares nunca mais os encontrassem, simplesmente eram dados como desaparecidos. Alguns mortos decorrentes das torturas eram dados como mortos por enforcamento nas prisões, uma forma de livrar a culpa dos torturadores. A repressão foi intensa no período de vigência do AI-5, que amparou o governo e o Estado legitimando as suas ações como necessárias para manter o regime político.

O AI-5 foi considerado pelos militares o melhor e maior ato de afirmação da ditadura no Brasil, pois legitimou a repressão em todos os sentidos, expulsando do país as pessoas que tinham comprometimento com a luta pela liberdade de expressão. Foi o período de maior saída de profissionais qualificados, pois muitos sofreram perseguições políticas. Foram anos de tensão inclusive para profissionais estrangeiros que vieram atuar profissionalmente no Brasil. Os imigrantes não eram bem aceitos, pois o governo temia que poderiam seguir ideologias políticas contrárias ao regime militar, foi um 
período de fechamento total das fronteiras. O Brasil, consequentemente, teve as maiores taxas de perdas de pessoas capacitadas, os estrangeiros não viam o país como alternativa para desenvolver suas funções profissionais. Esse ato decisivamente criou uma clausura, ficamos fechados para o mundo, vivíamos em torno de um regime político centralizador e repressivo cujo o slogan era ame-o ou deixe-o, os que puderam deixaram, os que ficaram teriam que amá-lo. O AI-5 configurou a ditadura em sua plenitude. Os que viveram 1968 jamais irão esquecê-lo, pois foi um ano de paradoxos, entre o sonho da imaginação e a realidade da repressão.

\section{CONCLUSÃO}

2018 completou cinquenta anos do Maio de 1968, essa data reforça alguns sentimentos, rememora outros e deixa um ponto de interrogação; onde ficaram os ideais de liberdade e imaginação daquela geração? Talvez o mundo não seja mais o mesmo, e realmente não é, mas ficou uma lição; a luta é sempre importante. Vivemos no Brasil uma onda de criminalização dos movimentos sociais, combatendo as formas de manifestações e a supressão dos direitos humanos duramente conquistados. Estamos em um outro contexto, em que a utopia nos parece mais distante. Os problemas sociais são outros, as pessoas estão mais interessadas em seu universo particular do que nas causas sociais. Perdeu-se um pouco da imaginação, nos tornamos mais pragmáticos, centrados em problemas existenciais, tudo o que é do outro pouco nos interessa. Atualmente os defensores dos direitos humanos são hostilizados, os direitos humanos são considerados como direitos de bandidos e de usurpadores sociais.

Talvez, cinquenta anos depois de 1968 tudo o que os jovens fizeram naquele ano emblemático seria considerado como um delírio da esquerda, o esvaziamento dos movimentos sociais com a apatia dos jovens, dos estudantes, dos operários, enfim de todos aqueles que ousavam protestar. Os protestos no mundo contemporâneo parecem não ter mais repercussão, os governos centralizadores não escutam mais o que a população quer falar, fazem medidas provisórias que inclusive ferem as Constituições dos países. Assistimos a um verdadeiro desmonte dos estados democráticos, os novos governantes estão do lado do capital, o bem-estar social deixa de existir a cada ano que 
passa. As novas gerações tendem a uma apatia, estão mais interessadas em seus problemas pessoais do que nos problemas que atingem as sociedades. O consumismo que foi combatido em 1968 voltou à tona no mundo atual, os jovens se tornaram os mais consumistas.

Toda a geração de 1968 hoje vive a nostalgia do que foi aquele ano emblemático, tanto os que participaram ativamente dos movimentos quanto os que foram apenas passivos a tudo o que aconteceu, as memórias ainda estão vivas. Os protagonistas tomaram rumos diferentes, alguns até conquistaram cargos nos governos democráticos, outros retomaram o ritmo natural de suas vidas. O que mais incomoda hoje os historiadores e cientistas sociais é essa memória subterrânea, ou seja, o não-dito, aquilo que ainda permanece no silêncio. Muitas pessoas em 1968 no Brasil foram presas e torturadas e não conseguiram expor, trazer à tona tudo o que sofreram. Foi preciso, no Brasil e em outros países da América do Sul, a criação das Comissões da Verdade para investigar os crimes que as ditaduras militares cometeram dentro do próprio Estado. Somente essas comissões foram capazes de investigar com clareza o que realmente aconteceu, trazer uma verdade histórica para a elucidação da memória.

Foi realmente um ano de paradoxos. Se no velho mundo pediam a imaginação no poder, no Brasil era uma tarefa impossível, pois tínhamos a repressão no poder, o que se configurou como estado de exceção. Não foi fácil para os estudantes brasileiros daquela época irem às ruas se manifestar e pedir pelos seus direitos. Direitos eram suprimidos, vivíamos anos de chumbo e de violações. Nada era garantido, nem o ato de manifestar-se, o que pode ser visto da Passeata dos 100 mil em 1968, a qual foi violentamente reprimida. Se Paris foi cenário de movimentos libertadores, o Brasil foi o palco dos horrores, da repressão, da supressão, da falta de tudo, sobretudo da liberdade. Os movimentos aconteceram em diferentes cenários, a partir de Paris, que foi o polo irradiador, o mundo conheceu a utopia dos jovens que sonhavam um mundo melhor, mais igualitário e menos repressor.

A grande lição de 1968 para o mundo foi a coragem de lutar por um mundo melhor, mais equitativo, menos opressor. Não foi fácil em nenhum dos cenários, trouxe ao palco das lutas a ousadia dos jovens estudantes, dos que acreditavam em uma sociedade mais justa. As cenas de 1968 foram díspares. Se em Paris nos confrontos com 
a polícia houve apenas pessoas machucadas, no México e no Brasil houve pessoas mortas. No Brasil, a repressão atingia o seu auge, era o apogeu da ditadura, estava implantado o Estado de Exceção, toda e qualquer manifestação era duramente combatida e reprimida pela polícia. Mas apesar de tudo, os jovens brasileiros foram ousados, continuaram a resistir, protestavam, cantavam os horrores que sofriam. Aqui também existiu uma arte engajada, tanto que o nome de uma música de Caetano Veloso chamava-se é proibido proibir, seguindo o slogan gritado pelos jovens em Paris.

A memória sobre 1968 cada vez mais se refaz a partir de novos olhares, seja dos que protagonizaram, seja dos que apenas assistiriam a tudo o que aconteceu. Os protagonistas nos deixam uma lição de coragem e ousadia; os outros, talvez a loucura dos jovens burgueses que protestavam. A memória se refaz cotidianamente, concebe novos significados em diferentes contextos. Realmente o mundo não é mais o mesmo, mas o ideal de lutas e a coragem de protestar ainda permanecem com muitos jovens. $\mathrm{O}$ grande legado da geração de 1968 foi a sua ousadia. Os jovens conclamavam mudanças, queriam um mundo mais justo e igualitário. O grande desafio da memória é recuperar o verdadeiro sentido desse ano tão emblemático. Para alguns foi um ano de lutas para outros talvez tenha sido um ano qualquer. Mas ficou marcado na memória social como um ano de ebulição, talvez esse seja o seu grande legado, que passados cinquenta anos, ainda é relembrado.

\section{REFERÊNCIAS}

BAUER, Caroline Silveira. Brasil e Argentina: ditaduras, desaparecimentos e políticas de memória. Porto Alegre: Medianiz, 2012.

BORIS, Fausto. História do Brasil. São Paulo: Edusp, 1995.

GASPARI, Elio. A ditadura envergonhada. São Paulo: Companhia das Letras, 2002.

HOBSBAWM, Eric. Era dos Extremos: o breve século XX: 1914-1991. São Paulo: Companhia das Letras, 1995.

MALTEZ, INFO. Micropoderes. Disponível: <http://maltez.info/respublica/Cepp/conceitos_politicos/micropoderes.htm>. Acesso em: 21 Out. 2018. 
MARTINS, Jasson da Silva. Agamben. In: Cadernos IHU. Ano IX, n. 45. São Leopoldo: Unisinos, 2013. Disponível em: < http://www.ihu.unisinos.br/images/stories/cadernos/formacao/45_cadernosihuemformac ao>. Acesso em 01 Out. 2018.

PEREIRA, Antony W. Ditadura e repressão: o autoritarismo e o estado de direito no Brasil, no Chile e na Argentina. São Paulo: Paz e Terra, 2010.

RUIZ, Castor M. M. Bartolomé. O campo como paradigma biopolítico moderno. In: Cadernos IHU em Formação: Agamben. Ano IX, n. 45, 2013. Disponível em: $<$ http://www.ihu.unisinos.br/images/stories/cadernos/formacao/45_cadernosihuemforma cao.pdf>. Acesso em 10 out. 2018.

SCHWARCZ, Lilia Mortiz; STARLING, Heloisa Murgel. Brasil: uma biografia. São Paulo: Companhia das Letras, 2015.

TRONCOSO, Alberto Del Castillo. O Movimento Estudantil de 1968 na Cidade do México visto através da fotografia. Disponível em: <https://periodicos.ufpe.br/revistas/revistaclio/article/viewFile/24192/19631>. Acesso em: 23 Ago. 2018, 09:33:12.

VEJA, Revista. Ter sido expulso da França me salvou', diz Cohn-Bendit a Bial. Disponível em: < https://veja.abril.com.br/entretenimento/ter-sido-expulso-da-franca-me-salvou-diz-cohnbendit-a-bial/>. Publicado em: 08 Mai.2018. Acesso em: 23 Ago. 2018, 09:22:01.

BARBOSA, Fernanda. Primavera de Praga foi movimento para "humanizar" o comunismo. Disponível em: < https://www1.folha.uol.com.br/folha/mundo/ult94u396937.shtml>. Acesso em: 23 Ago. 2018, 07:32:11. Publicado em: 30 de abril de 2008. Acesso em: 23 Ago. 2018, 07:32:11.

VENTURA, Zuenir. 1968: o ano que não acabou. São Paulo: Nova Fronteira, 1988.

Recebido em: 13/072018 Aprovado em: 17/112018 